\title{
PROFIL KEMAMPUAN LIT ERASISAINS SISWA SMP DI KOTA PURWOKERTO DITINJAU DARI ASPEK KONTEN, PROSES, dan KONTEKS SAINS
}

\author{
Mufida Nofiana ${ }^{1}$, Teguh Julianto ${ }^{2}$ \\ Universitas Muhammadiyah Purwokerto
}

\begin{abstract}
Abstrak. Literasi sains menurut PISA (Prgram for international student assessment) adalah kemampuan menggunakan pengetahuan ilmiah, mengidentifikasi pertanyaan dan menggambarkan bukti-bukti yang berdasarkan kesimpulan untuk dapat memahami dan membantu pembuatan kesimpulan tentang alam serta perubahan terhadap alam tersebut akibat aktivitas manusia. Literasi sains bersifat multidimensional. Individu yang "melek sains" adalah orang yang menggunakan konsep sains, keterampilan proses, dan nilai dalam membuat keputusan sehari-hari jika berhubungan dengan orang lain atau dengan lingkungannya, serta memahami interlasi anatara sains, teknologi dan masyarakat, termasuk perkembangan social dan ekonomi. Penelitian ini merupakan penelitian deskriptif, yaitu penelitian yang bertujuan untuk menggambarkan profil capaian literasi sains siswa SMP di kota purwokerto yang ditinjaau dari tigas aspek listerasi sains, yakni konten, proses, dan konteks. Penelitian dilakakukan pada siswa kelas 8 di SMP Negeri 1 Purwokerto, SMP Negeri 8 Purwokerto, dan SMP Muhammadiyah 1 Purwokerto dengan total responden berjumlah 184 siswa. Penelitian dimulai dengan tahap persiapan untuk mendapatkan soal literasi sains tingkat SMP yang valid. Selanjutnya, tahap pengambilan data yang dilakukan dengan mengambil jawaban-jawaban siswa yang mengerjakan soal tes literasi sains selama 90 menit. Tahap terakhir adalah perhitungan presentase capaian per setiap aspek literasi. Hasil penelitian menunjukkan bahwa rata-rata prosentase kemampuan literasi sains siswa SMP di kota purwokerto masih rendah pada 3 aspek literasi sains yaitu aspek konten (53,80\%), aspek proses (44,038\%) dan aspek konteks (35,088\%). Rendahnya salah satu aspek literasi sains akan berpengaruh terhadap aspek literasi sains lainnya. Rendahnya pemahaman konsep siswa terhadap pengetahuan sains akan berdampak pada rendahnya aplikasi sains. Saat ini siswa-siswa di tiga SMP di kota purwokerto yang menjadi subyek penelitian hanya memiliki kemampuan mengingat pengetahuan ilmiah berdasarkan fakta sederhana. Hasil pengukuran literasi sains yang dilakukan pada siswa-siswa SMP di kota purwokerto dapat menjadi acuan dalam memetakan kemampuan sains (IPA) dan kualitas pembelajaran sains (IPA) siswa SMP di kota Purwokerto
\end{abstract}

Kata kunci: profil literasi sains; aspek literasi sains

\section{PENDAHULUAN}

Literasi sains menurut PISA (2010) adalah kemampuan menggunakan pengetahuan ilmiah, mengidentifikasi pertanyaan dan menggambarkan buktibukti yang berdasarkan kesimpulan untuk dapat memahami dan membantu pembuatan kesimpulan tentang alam serta perubahan terhadap alam tersebut akibat aktivitas manusia. Literasi sains merupakan tujuan yang ingin dicapai oleh mata pelajaran-mata pelajaran yang berumpun pada sains, yang salah satunya adalah biologi. Standar kompetensi lulusan pada kelompok mata pelajaran IPA (sains) kurikulum 2006 menyebutkan bahwa 
sains berkaitan dengan cara mencari tahu tentang alam secara sistematis, sehingga sains bukan hanya penguasaan kumpulan pengetahuan yang berupa fakta, konsepkonsep, atau prinsip-prinsip saja tetapi juga merupakan suatu proses penemuan.

Pesatnya perkembangan sains dan teknologi di abad 21 menuntut manusia semakin bekerja keras menyesuaikan diri dalam segala aspek kehidupan. Salah satu kunci sukses menghadapi tantangan abad 21 adalah "melek sains" (science literacy) sebab individu yang melek sains dapat emnggunakan informasi ilmiah yang dimilikinya untuk mengatasi masalah dalam kehidupan sehari-hari serta menghasilkan produk-produk ilmiah yang bermanfaat. Pendidikan sains memiliki peran yang penting dalam menyiapkan indvidu memasuki dunia kehidupannya. Mudzakir (dalam marta 2013) menngemukakan bahwa pendidikan sains memiliki potensi yang besar dan peranan srategis dalam menyiapkan sumber daya manusia yang berkualitas untuk menghadapi era industrialisasi dan globalisasi. Potensi ini akan terwujud jika pendidikan sains mempu melahirkan siswa yang cakap dalam bidangna dan berhasil menumbuhkan kemampuan berpikir logis, kreatif, mampu memecahkan masalah, kritis, menguasai teknologi serta adaptif terhadap perubahan dan perkembangan zaman.

PISA- OECD (Programe for International Student Assessment-Organisation for Economic Cooperation and Development) telah melakukan suatu pemonitoran mengenai kemampuan literasi sains siswa Indonesia. Sejak tahun 2000 - 2012, prestasi siswa Indonesia dalam kompetisi sains international mengalami penurunan. Pada tahun 2009, peringkat indonesia berada pada urutan 60 dari 65 negara peserta. Pada tahun 2012, peringkat indonesia mengalami penurunan menjadi peringkat 64 dari 65 negara peserta. Pada tahun 2016, peringkat indonesia naik menjadi 62 dari 70 negara peserta.

Hasil temuan tersebut mengindikasikan bahwa secara umum literasi sains siswa Indonesia masih rendah meskipun telah terjadi peningkatan pada tahun 2016. Oleh karena itu diperlukan upaya-upaya perbaikan terhadap pembelajaran sains di sekolah. Upaya perbaikan kualitas pembelajaran di sekolah harus didukung dengan informasi yang akurat tentang sejauh mana pencapaian literasi sains siswa khususnya siswa SMP yang merupakan siswa usia wajib belajar 9 tahun. Profil kemampuan literasi sains siswa SMP dapat menjadi bekal bagi guru maupun stakeholders untuk meningkatkan kualitas pendidikannya di sekolah sehingga menjadi tepat sasaran sesuai dengan harapan kurikulum. Pengukuran kemampuan literasi sains dapat ditinjau dari aspek-aspek literasi sains meliputi aspek konten, proses, dan konteks.

\section{METODE PENELITIAN}

Penelitian ini menggunakan metode penelitian deskriptif, yaitu penelitian yang bertujuan untuk menggambarkan profil capaian literasi sains siswa SMP di kota Purwokerto yang ditinjaau dari tigas aspek listerasi sains, yakni konten, proses, dan konteks. Penelitian dilakakukan pada siswa kelas 8 di SMP Negeri 1 Purwokerto, SMP Negeri 8 Purwokerto, dan SMP Muhammadiyah 1 Purwokerto dengan total responden berjumlah 184 siswa. Penelitian dimulai dengan tahap persiapan. Tahap persiapan dilakukan sebelum pelaksanaan penelitian.

Skor lietrasi sains dihitung dengan teknik presentase per setiap aspek literasi, selanjutnya hasil yang diperoleh diinterpretasikan dengan tabel kriteria seperti berikut ini. 
Tabel 4.1. Kriteria Interpretasi Skor

(Djaali dan Muljono, 2008)

\begin{tabular}{cc}
\hline Interval kriteria & Kriteria \\
\hline $86 \% \leq \mathrm{N}<100 \%$ & Sangat baik \\
$72 \% \leq \mathrm{N}<85 \%$ & Baik \\
$58 \% \leq \mathrm{N}<71 \%$ & Cukup \\
$43 \% \leq \mathrm{N}<57 \%$ & Rendah \\
$\mathrm{N} \leq 43 \%$ & Sangat Rendah \\
\hline
\end{tabular}

Instrumen literasi sains yang digunakan diadopsi dari Take the test sample question from OECD'S PISA assesment dan berjumlah 20 soal literasi sains yang terdiri dari 6 soal untuk aspek konten sains, 9 soal untuk aspek proses sains, dan 5 soal untuk aspek konteks sains.

\section{HASIL DAN PEMBAHASAN}

Instrumen literasi sains yang digunakan diadopsi dari Take the test sample question from OECD'S PISA assesment dan berjumlah 20 soal literasi sains yang terdiri dari 6 soal untuk aspek konten sains, 9 soal untuk aspek proses sains, dan 5 soal untuk aspek konteks sains.

Hasil penelitian literasi sains pada 3 SMP di kota purwokerto disajikan pada tabel 2 dan diagram 1.

Tabel 4.2. Presentase kemampuan literasi sains siswa SMP di kota Purwokerto

\begin{tabular}{|l|l|l|l|}
\hline Nama sekolah & Konten (\%) & Proses (\%) & Konteks (\%) \\
\hline SMP N 1 Purwokerto & 48,27 & 35,13 & 32,69 \\
\hline SMP N 8 Purwokerto & 53,40 & 44,27 & 42,54 \\
\hline SMP Muhammadiyah 1 Purwokerto & 29,01 & 30,61 & 21,20 \\
\hline Rata-rata & $\mathbf{4 3}, \mathbf{5 6}$ & $\mathbf{3 6 , 6 7}$ & $\mathbf{3 2 , 1 4}$ \\
\hline
\end{tabular}

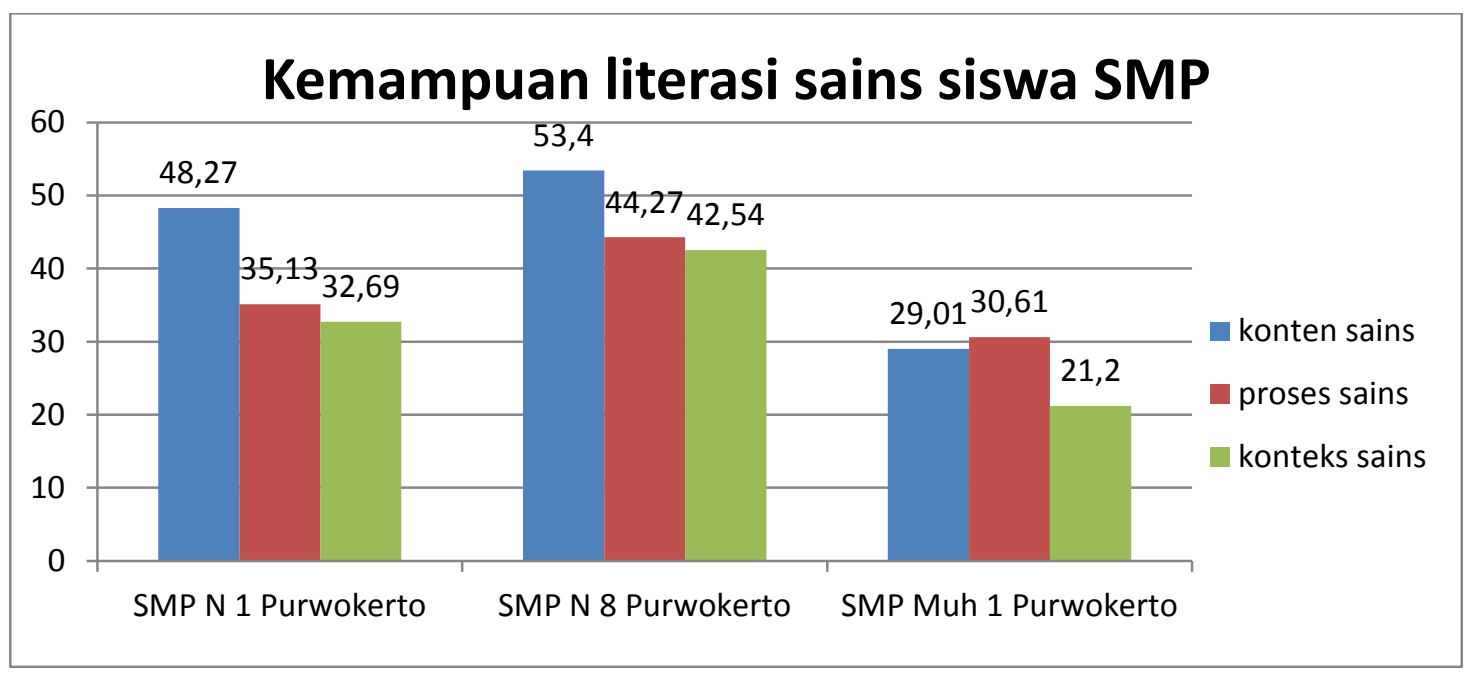

Diagram 4.1. Kemampuan Literasi Sains Siswa SMP

\section{Aspek konten sains}

Hasil penelitian profil literasi sains tingkat SMP di kota Purwokerto berdasarkan Tabel 2 mennjukkan rata-rata posentase kemampuan literasi sains siswa pada aspek konten sebesar $43,56 \%$ atau dalam kategori rendah.

Konten sains merujuk pada konsepkonsep kunci yang diperlukan untuk memahami fenomena alam dan perubahan yang dilakukan terhadap alam melalui 
aktivitas manusia. Dalam kaitan ini, PISA tidak secara khusus membatasi cakupan konten sains hanya pada pengetahuan yang menjadi materi kurikulum sains sekolah, namun termasuk pula pengetahuan yang dapat diperoleh melalui sumber-sumber informasi lain yang tersedia.

PISA menentukan kriteria pemilihan konten sains sebagai berikut:

a. Relevan dengan situasi kehidupan nyata

b. Merupakan pengetahuan penting sehingga penggunaanya berjangka panjang

c. Sesuai untuk tingkat perkembangan anak usia 15 tahun

Berdasarkan kriteria konten tersebut, maka dalam konten sains dipilih pengetahuan yang diperlukan untuk memahami dan memaknai pengalaman dalam konteks personal, sosial, dan global meliputi bidang-bidang studi biologi, fisika, kimia, serta ilmu pengetahuan bumi dan antariksa dengan merujuk pada kriteria tersebut.

Hasil penelitian menunjukkan kemampuan literasi sains siswa SMP di kota purwokerto dalam aspek konten sains masih rendah. Meskipun pembelajaran IPA di SMP lebih menekankan pada pengusaan aspek konten, namun kenyataanya penguasaan konsep siswa tentang IPA masih rendah. Adanya tuntutan terselesaikannya materi bahan ajar oleh guru sesuai target kurikulum memaksa siswa harus menerima konsepkonsep IPA yang mungkin belum sepenuhnya dipahami. Hal ini menjadikan banyak konsep-konsep IPA dipahami secara salah (miskonsepsi) atau hanya sekedar dihafalkan yang pada akhirnya konsep tersebut mudah dilupakan.

Contoh soal iterasi sains pada aspek konten yang diujikan pada saat penelitian

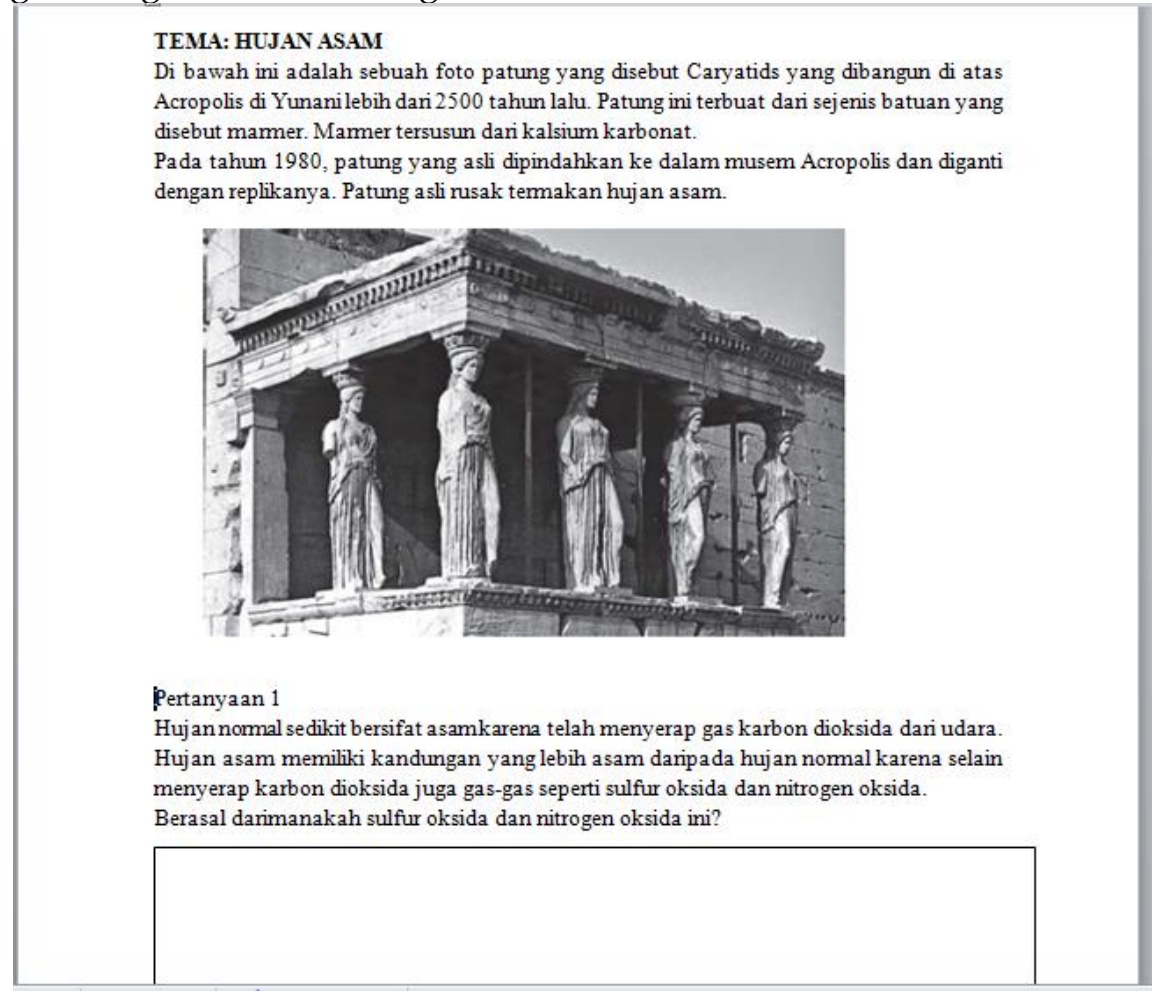

2. Aspek proses sains 
Hasil penelitian profil literasi sains tingkat SMP di kota Purwokerto berdasarkan Tabel 2 mennjukkan rata-rata posentase kemampuan literasi sains siswa pada aspek proses hanya sebesar 36,67\% atau dalam kategori sangat rendah.

Proses sains merujuk pada proses mental yang terlibat ketika mwnjawab suatu pertanyaan atau memecahkan masalah seperti mengidentifikasi dan menginterpretasi bukti serta menerangkan kesimpulan. Termasuk di dalamnya mengenal jenis pertanyaan yang dapat dan tidak dapat dijawab oleh sains, mengenal bukti apa yang diperlukan dalam suatu penyelidikan sains, serta mengenal kesimpulan sesuai dengan bukti yang tersedia.

PISA memandang pendidikan sains berfungsi untuk mempersiapkan warga negara masa depan. Oleh karena itu pendidikan sains perlu mengembangkan kemampuan peserta didik memahami hakekat sains, prosedur sains, serta kekuatan dan kelemahan sains. Proses kognitif yang terlibat dalam proses sains antara lain penalaran induktif/ deduktif, berpikir kritis dan terpadu, pengubahan representasi, mengkonstruksi ekplanasi berdasarkan data, serta berpikir dengan menggunakan model (Zuriyani, 2012)

Hasil penelitian menunjukkan kemampuan literasi sains siswa SMP di kota purwokerto dalam aspek proses sains masih sangat rendah. Berdasarkan hasil pengamatan di sekolah, proses pembelajaran IPA di SMP masih sekedar transfer pengetahuan dari guru kepada siswa yang dilakukan secara verbal sehingga kurang menekankan pada proses. Akibatnya siswa memahami konsepkonsep IPA hanya sebagai hafalan. Padahal Carin dan Sund (dalam PuskurDepdiknas, 2006) mendefinisikan sains sebagai pengetahuan yang sistematis atau tersusun secara teratur, berlaku umum, dan berupa kumpulan data hasil observasi dan eksperimen.

Aktivitas dalam sains selalu berhubungan dengan percobaanpercobaan yang membutuhkan keterampilan dan kerajinan. Dengan demikian, sains bukan hanya kumpulan pengetahuan tentang benda atau makhluk hidup tetepi menyangkut cara kerja, cara berpikir, dan cara memecahkan masalah.

Contoh soal iterasi sains pada aspek proses yang diujikan pada saat penelitian

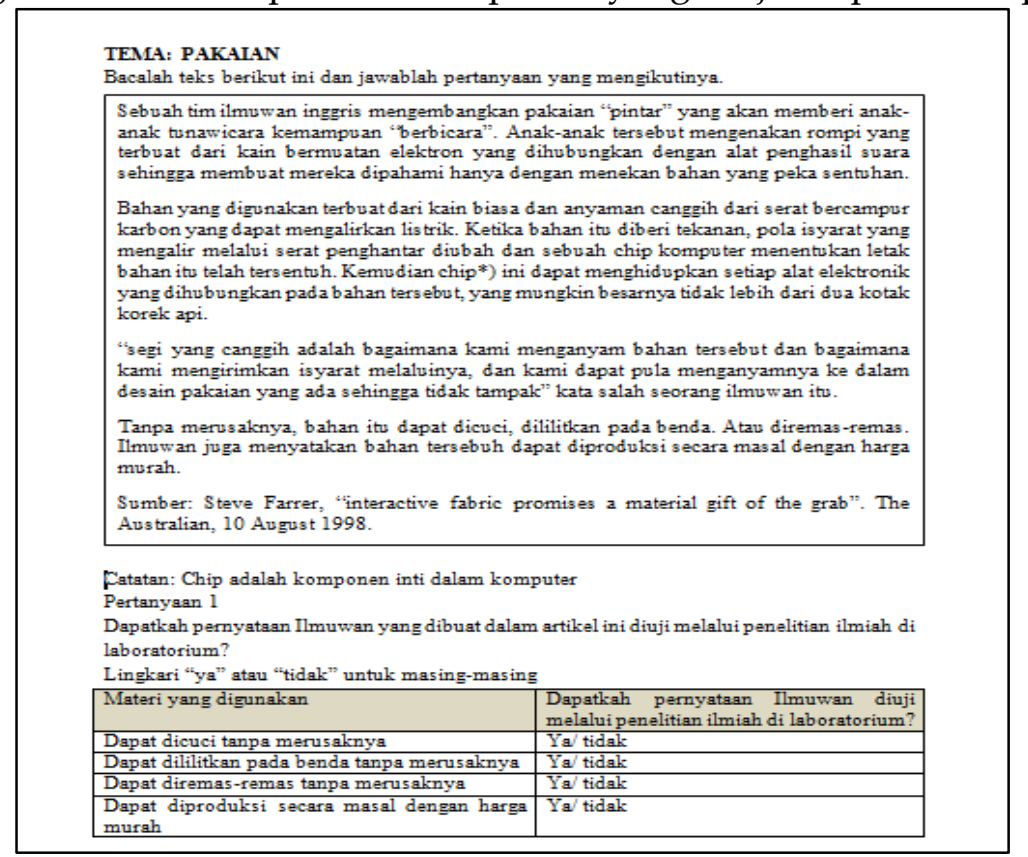




\section{Aspek konteks sains}

Hasil penelitian profil literasi sains tingkat SMP di kota Purwokerto berdasarkan Tabel 2 mennjukkan ratarata posentase kemampuan literasi sains siswa pada aspek konteks hanya sebesar $32,14 \%$ atau dalam kategori sangat rendah.

Konteks sains merujuk pada situasi dalam kehidupan sehari-hari yang menjadi lahan bagi aplikasi proses dan pemahaman konsep sains. Dalam kaitan ini PISA membagi bidang aplikasi sains ke dalam tiga kelompok, yakni kehidupan dan kesehatan, bumi dan lingkungan, serta teknologi. Situasi nyata yang menjadi konteks aplikasi sains dalam PISA tidak secara khusus diangkat dari materi yang dipelajari di sekolah, melainkan diangkat dari kehidupan sehari-hari.

Hasil penelitian menunjukkan kemampuan literasi sains siswa SMP di kota purwokerto dalam aspek konteks sains masih sangat rendah. Jika dianalisis, pembelajaran IPA di SMP khususnya di kota purwokerto masih dilakukan secara parsial (terpisah) atau belum terpadu, akibatnya konsep IPA yang diterima oleh siswa juga terpisah. Kecenderungan guru untuk memberikan materi tanpa mengaitkannya dengan kehidupan nyata menyebabkan siswa kesulitan mengaitkan pengetahuan yang telah didapatkan dengan situasi kehidupan nyata. Hal ini terlihat dari jawabanjawaban siswa yang masih sangat teoritik sesuai dengan konsep materi yang diajarkan di sekolah dan belum mampu mengaplikasikan konsep materi untuk memecahkan masalah-masalah sains yang dijumpai di dalam soal.

Ibrahim dan Aspar (2006) mengemukakan keterkaitan antara dimensi-dimesi literasi sains. Rendahnya salah satu dimensi literasi sains akan berpengaruh terhadap dimensi literasi sains lainnya. Rendahnya pemahaman konsep siswa terhadap pengetahuan sains akan berdampak pada rendahnya aplikasi sains. Fakta di lapangan menunjukkan meskipun siswa sangat pandai menghafal namun juga kenyataanya kurang terampil dalam mengaplikasikan pengetahuan yang dimilikinya.

Kemampuan literasi sains yang tinggi penting untuk dimiliki oleh setiap siswa di Indonesia, hal ini disebabkan karena kemampuan literasi sains berperan dalam menentukan kemajuan suatu bangsa. Peringkat Indonesia yang masih sangat rendah dalam penilaian literasi sains dunia mencerminkan bagaimana sistem pendidikan Indonesia yang sedang berjalan saat ini. Skill membaca siswa Indonesia masih sangat rendah. Budaya membaca terkait dengan kemauan "memaksa diri" untuk membeli buku dan kemauan meluangkan waktu untuk membacanya masih rendah. Padahal literasi sains siswa tidak akan tumbuh jika kemauan dan kesadaran untuk membaca tidak dimiliki oleh setiap siswa.

Kemampuan literasi sains berkaitan erat dengan kemampuan riset siswa. Kemampuan riset yang dimiliki oleh siswa akan berpengaruh pada upaya melahirkan penemuanpenemuan baru yang datang dari dunia pendidikan. Berdasarkan data hasil penelitian, saat ini siswa-siswa di tiga 
SMP di kota purwokerto yang menjadi subyek penelitian hanya memiliki kemampuan

mengingat pengetahuan ilmiah berdasarkan fakta sederhana. Proses pembelajaran IPA yang lebih sering menekankan pada abstract conceptualization dan kurang mengembangkan active experimentation serta rendahnya budaya membaca dan
TEMA: OZON

Bacalah artikel tentang lapisan ozon benkut ini.

Atmosfer adalah lautan udara dan sumber daya alam yang berharga untuk keberlangsunganhidup dibumi. Sayangnya, beberapa aktivitas manusia menyebabkan hal yang berbahaya pada atmosfer, tenutama menyebabkan teja dinya penipisan lapisan ozon, dimana ozon berperan sebagai penisai pelindung bag k kehidupan di bumi.

Molekul ozonmenganding tiga atomoksigen, sebaliknva, molekul oksigen menganding dua atom oksigen. Molekul ozon sangat jarang dijumpai diudara karena hanya ada sepuluh dar satujuta molekul diudara. Selama hampir satumilyar tahn, kehadiran ozondi atmosfer memiliki peran penting dalam melindung kehidupan di bumi. Namun, berdasarkan lokasi kebera daarnya, ozon dapat melindung sekaligus membahayakan kehidupan bumi. Ozon yang berada dilapisan Troposfer (terletak di atas 10 kilometerpemukaanbumi) adalah ozon yang "buruk" karenamembahayakan marusia dan tumbuhan Tetapi, sekitar 90 persen ozon yang ditemukan di Stratosfer (terletak antara 10 sampai $40 \mathrm{~km}$ di atas permukaan bumi) adalah ozon yang "baik" karena mampumenyerap radasi sinarultraviolet berbahaya (UV-B) dari cahaya matahari

Tanpa lapisan ozon, manusia lebih rentan terhadap penyakit tertentu karena adanya peningkatan sinar ultraviolet dari matahari. Dalam satu dekade terakhir, jumlah ozon mengalami penuruman. Pad tahun 1974, ada sebuah hipotesis yang menvatakan bahwa Chlorofluorocarbons ( $\mathrm{CFC}$ s)merupakan penyebab penurunanjumlahozon tersebut. Sampai dengan tahn 1987, imuwanmelakukan perilaiantentang hubungan antara penyebab dan efek CFCs, namunkesimpulan yang didapat oleh para ilmuwan tidak cukup meyakinkan Pada september 1987, pervakilan negara dari beberapa baģian dunia bertemu di Montreal (Canada) dan sepakat untuk mengatur penggunaan CFCs.

Sumber: Connect, UNESCO intemational science, technology \& enviromental education nevsletter, section from an article entitled "the chemsitry of atmospheric policy" vol XII, No 2,1997 menulis pada siswa menjadi salah satu penyebab rendahnya kemampuan literasi sains siswa SMP di kota purwokerto.

Contoh soal iterasi sains pada aspek proses yang diujikan pada saat penelitian
Pertanyaan 1

Pada teks tidak disebutkan cara pembentukan ozon di atmosfer. Faktanya setiap hari beberapa ozon diberntuk namm beberapa lainnya juga menghilang. Cara terbentuknya ozon dapat dillustrasikan seperti potongan komik benkut ini.

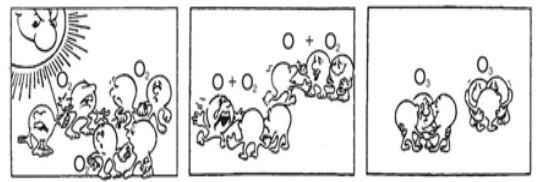

Seorang temanmumencoba memahami arti darikomik tersebut, namm dia tetap tidak paham denganmakna yang dijelaskanpada komik tersebut Temarmu hanya memahami bahwa di atmosfertidak mungkin ada anak kecil seperti pada gambar. Dia memintamu membantu menjelaskan komik tersebut. Temanmu sudah mengetahui bahwa:

a. Simbol 0 adalah simbol untuk atom oksigen

b. Gambar komik tersebut merupakan cara pembentukan molekul ozon dari atom oksigen

TTuliskan penjelasarmutentangpotongankomik tersebut (gunakan kata atom dan molekul yang digunakan pada poin $\mathrm{a}$ dan $\mathrm{b}$ )
Pembelajaran merupakan kegiatan mengajar ditinjau dari sudut kegiatan siswa berupa pengalaman belajar siswa. Pembelajaran sains selama ini kurang relevan dan kurang populer di mata para siswa SMP. Hal ini dikarenakan kurikulum yang digunakan di sekolah cenderung menempatkan materi subyek terlebih dahulu kemudian sedikit aplikasinya. Padahal penerapan prinsipprinsip sains harus berjalan seimbang sehingga dapat digunakan untuk memecahkan masalah atau mengambil keputusan yang berkenaan dengan masalah sehari-hari.

\section{PENUTUP}

\section{Kesimpulan}

Pengukuran profil literasi sains berdasarkan aspek-aspek literasi sains meliputi aspek

konten, proses, dan konteks sains sebagaimana yang dikembangkan oleh PISA sangat relevan dengan hakikat pembelajaran sains (IPA). Hasil pengukuran literasi sains yang dilakukan pada siswa-siswa SMP di kota purwokerto dapat menjadi acuan dalam memetakan kemampuan sains (IPA) dan kualitas pembelajaran sains di kota purwokerto. Berdasarkan hasil penelitian dapat dikemukanan profil literasi sains siswa 
SMP di kota Purwokerto adalah rata-rata prosentase kemampuan literasi sains siswa SMP di kota purwokerto masih rendah pada 3 aspek yaitu aspek konten (53,80\%), aspek proses $(44,038 \%)$ dan aspek konteks $(35,088 \%)$.

\section{SARAN}

1. Perlunya dikembangkan perangkat pembelajaran yang menunjang pelaksanan literasi sains di SMP

2. Perlunya peningkatan dan pembiasaan budaya membaca/ literasi di kalangan siswa SMP oleh guru-guru di sekolah.

\section{DAFTAR PUSTAKA}

[1] Amri, Ulil. 2010. Pengembangan instrumen penilaian literasi sains fisika siswa pada aspek konten, proses, dan konteks. PMIPA FKIP - Universitas Riau.

[2] Djaali dan Pudji Mulyono. 2008.

Pengukuran dalam Bidang Pendidikan. Jakarta: Grasindo.

[3] Ibrahim M.A \& Apar, Nor Hafiz. 2006. Tahap Literasi Sains dalam Kalangan Pelajar Tingkatan Empat Sekolah Akhir Agama di Daerah Hilir Perak. Perak: UTM.

[4] Marta, Febrian Andi. 2013. Analisis literasi

sains siswa smp dalam pembelajaran IPA terpadu pada tema efek rumah kaca.

Universitas Pendidikan Indonesia

[5] OECD. 2013. PISA 2012 Results. OECD publishing

[6] Odja, Abdul Haris. 2014. Analisis kemampuan awal literasi sains siswa pada konsep IPA. Prosiding seminar nasional kimia, ISBN: 978-602-0951-00-3

[7] Permendiknas. 2006. Peraturan Menteri Pendidikan Nasional Republik Indonesia
No. 23 tentang Standar Kompetensi Lulusan untuk Satuan Pendidikan Dasar dan Menengah. Jakarta: Depdiknas.

[8] PISA. 2010. Assesing framework key competencies in reading, mathematics, and science. OECD Publishing

[9] Rustaman, N.Y., Firman H., Kardiawarman. 2004. Literasi sains anak indonesia 2000. Bahan presentasi seminar nasional dijakarta

[10]Rahmawati, dewi. 2012. Analisis literasi sains siswa SMP dalam pembelajaran IPA terpadu pada tema penerapan bioteknologi konvensional. Universitas pendidikan indonesia.

[11] Soobard, R \& Rannikmae, M. 2011. Assesing student's level of scientific literacy using interdisciplinary scenarios.

Science education international. 133-144.

[12] Zuriyani, Elsy. 2012. Literasi Sains dan Pendidikan. Sumatera Selatan: sumsel.kemenag.go.id 